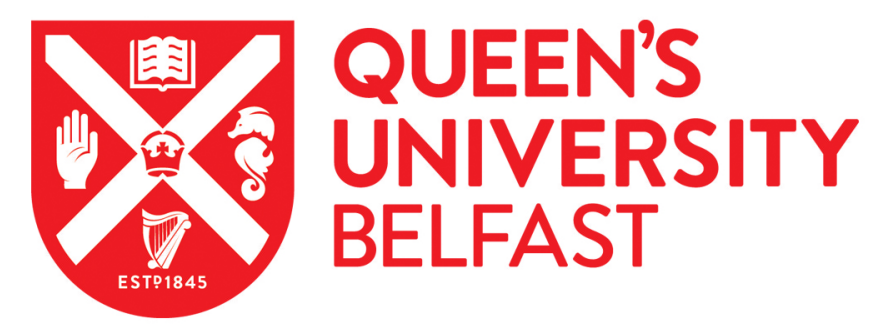

\title{
Death and Birth in the Urban Landscape: Strabo on Troy and Rome
}

Pfuntner, L. (2017). Death and Birth in the Urban Landscape: Strabo on Troy and Rome. Classical Antiquity, 36(1), 33. https://doi.org/10.1525/ca.2017.36.1.33

Published in:
Classical Antiquity

Document Version:

Peer reviewed version

Queen's University Belfast - Research Portal:

Link to publication record in Queen's University Belfast Research Portal

\section{Publisher rights}

(ङ) 2017 by the Regents of the University of California/Sponsoring Society or Association. This work is made available online in accordance with the publisher's policies. Please refer to any applicable terms of use of the publisher.

\section{General rights}

Copyright for the publications made accessible via the Queen's University Belfast Research Portal is retained by the author(s) and / or other copyright owners and it is a condition of accessing these publications that users recognise and abide by the legal requirements associated with these rights.

Take down policy

The Research Portal is Queen's institutional repository that provides access to Queen's research output. Every effort has been made to ensure that content in the Research Portal does not infringe any person's rights, or applicable UK laws. If you discover content in the Research Portal that you believe breaches copyright or violates any law, please contact openaccess@qub.ac.uk. 
Preprint, accepted for publication in Classical Antiquity (April 2017).

\section{Death and Birth in the Urban Landscape: \\ Strabo on Troy and Rome}

\section{Abstract}

Although Strabo provides lengthy accounts of Troy and Rome in the Geography, the role of these cities in his geographical thinking has received little attention from scholars. This article argues that for Strabo, Rome and Troy serve as exemplars of the progression of human civilization from Homeric prehistory to the Augustan present. They are paradigmatic "rising" and "fallen" cities, through which the lifecycles of all cities in the oikoumene can be understood. Moreover, in his treatment of the fall of Troy and the rise of Rome, Strabo departs from his Augustan-era contemporaries by emphasizing the historical interactions of each city with its respective region, rather than Rome’s purported Trojan origins. In describing Rome’s expansion into Latium (Book Five) and the post-Trojan War history of the Troad (Book Thirteen), Strabo emphasizes the mutability of urban landscapes through the destruction of existing cities and the creation of new ones - two processes in which Rome has played a significant role, and which continue to shape human settlement across the oikoumene.

Key words

Strabo, Rome, Troy, Latium, Troad, city, urbanism, destruction, foundation, geography, Homer, Augustus, polis

Introduction 
Troy and Rome are the two cities that Strabo treats most extensively in the seventeen books of his Geography. ${ }^{*}$ The history and topography of Rome alone take up five sections of Book Five (5.3.2-4 and 7-8 ${ }^{1}$ ), and Rome dominates the rest of Latium both historically and structurally: its history overshadows that of neighboring cities (5.3.2-6), and the roads emanating from it form the backbone of the rest of Strabo's description of central Italy (5.3.9-13). Likewise, Troy dominates Strabo's account of the Troad at the beginning of Book Thirteen: its historical geography takes up eleven of the seventy sections devoted to the region (13.1.25-27 and 35-42²). Although Alexandria in Egypt, Strabo's home for a time, also receives extensive treatment (17.1.6-13), such historically significant cities as Athens (9.1.16-20) and Carthage (17.3.14-15) are relatively overlooked in comparison. ${ }^{3}$ Yet, as I argue below, the fundamental role that Rome and Troy play in Strabo's conception of human geography - that is, the interactions of humans

\footnotetext{
* I thank Alain Gowing and the anonymous referees for their comments and corrections, and Ralph Hexter and Susanna Elm for their feedback on early versions of this article.

${ }^{1}$ 228-231C and 234-236C (the traditional pagination based on Isaac Casaubon's 1620 edition). ${ }^{2}$ 592-595C and 599-602C.

${ }^{3}$ Alexandria is a special case because Strabo's many years of residence there enabled him to give an especially thorough description; his account is still fundamental to studies of the ancient city's topography (e.g., McKenzie 2007: 173-76). Strabo’s inconsistent treatment of cities throughout the Geography has been criticized by modern scholars. For example, Pédech (1971: 252) laments Strabo’s relative inattention to such “important” cities as Syracuse, Miletus, Rhodes, Byzantium, and Pergamon.
} 
with their natural environment across time and space - has not been fully appreciated, either in scholarship on Strabo or in broader studies of Greek and Latin literature of the Augustan era.

Strabo's long life - much of which was devoted to the scholarship that formed the basis of

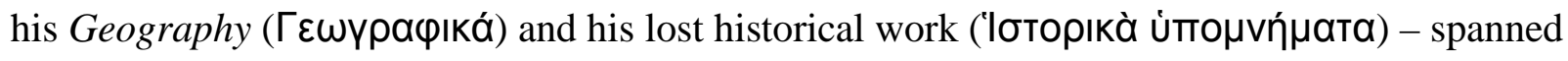
Pompey's reorganization of Asia Minor in the late 60s BC, the rise of Julius Caesar, the Roman civil wars, the Principate of Augustus, and the first decade of Tiberius’ reign. Born in Pontus, Strabo began his education at Nysa under the tutelage of Aristodemos, the son of the Homeric scholar Menekrates (14.1.48). From young manhood on, by his own account, Strabo spent significant spans of time (probably amounting to decades) in Rome and Alexandria. ${ }^{4}$

Given Strabo's education in the leading Hellenic schools of the first century BC and his exposure to Augustan-era intellectual circles in Rome (even if he was, at best, a peripheral member of such circles), his emphasis on the history and topography of Troy and Rome is hardly surprising. Since the archaic period, myths of Trojan origins had served to connect Greeks to the populations - including Romans and other Italic peoples - that they encountered as they settled across the Mediterranean; in turn, the alleged Trojan origins of the Romans proved useful in establishing friendly relations with Greek and Hellenized populations as imperium Romanum extended into Sicily and the Eastern Mediterranean in the third and second centuries BC. ${ }^{5}$ However, Rome's myth of Trojan origins had its greatest cultural and political impact in Strabo's

\footnotetext{
${ }^{4}$ See especially Dueck 2000 for Strabo's education, travels, and time in Rome.

${ }^{5}$ See Erskine 2001: 131-97 for an overview of these developments. Urso 2001 discusses an early instance of such links found in Strabo's brief account of diplomacy between Rome, Antium, and the Macedonians (5.3.5).
} 
lifetime, as Julius Caesar and his adopted son Octavian/Augustus promoted their descent from the Trojan refugee (and son of Venus) Aeneas. The link between the fall of Troy and the foundation of Rome is most famously and fully elaborated in Vergil's Aeneid; as has often been remarked, the epic’s first lines take the reader from Troy (1.1: Troiae qui primus ab oris) all the way up to the walls of Rome (1.7: altae moenia Romae) ${ }^{6}$ Many other Greek and Roman writers of Strabo's time - from the poets Ovid, Horace, and Propertius to the historians Livy and Dionysius of Halicarnassus - either evoke or explicitly discuss legends of Rome’s Trojan origins. $^{7}$

While we might expect Strabo, as a Greek scholar working under Augustus, to devote considerable space to the histories of Troy and Rome, yet more significant than the length of Strabo's individual treatments is the role of these two cities in shaping the Geography as a whole. In the pages that follow, I show how Troy and Rome embody Strabo's understanding of urban lifecycles, and how they serve as hermeneutic devices for exploring the causes of urban growth and decline over the wide chronological and geographical space of the inhabited world (the oikoumene $).{ }^{8}$

${ }^{6}$ E.g., recently, Nelis 2015: 28. Most notably, Troy is revived (in word, but not in reality) in Aeneas’ narrative of its fall to Dido in Book Two. Hardie 2013 examines this account as an instance of the "layering of later Roman history" (108) onto the pre-Roman topographies of the Aeneid.

${ }^{7}$ For Rome’s Trojan origins in the Augustan poets, see Edwards 1996: 52-66; in Livy, Kraus 1994; in Dionysius, Erskine 2001: 24-26.

${ }^{8}$ See Clarke 1999: 264-81 for the significance of urban lifecycles in Strabo. 
The shape of Strabo’s description of each city hints at this broader significance. Within his account of the Troad, Strabo fills the physical void left by the complete destruction of Troy by accounting for the site's subsequent history, and for the fates of its survivors and of the fabric of the city itself (13.1.38-42; cf. 13.1.53). In his discussion of Rome, which comes midway through Book Five's peregrination of central Italy, Strabo eschews a lengthy description of the city's topography - his account grows terse once he moves beyond the Campus Martius (5.3.8) instead placing a greater emphasis on its historical development and relationship with Latium (5.3.2-4).

Nowhere in the Geography does Strabo explicitly define the polis or outline his approach to describing cities as features of the physical and historical landscape. However, even from a cursory reading of the Geography it is clear that cities are an important element of Strabo's geographical descriptions, along with the natural features and phenomena (rivers, harbors, mountains, springs, etc.) and groups of people (and their histories, customs, and forms of organization) that distinguish one place from another. ${ }^{9}$

Strabo's treatment of cities, however, differs from his handling of other aspects of geography, and occupies a unique place in his work. Cities are containers of human memory, and they serve as the main vehicles for Strabo's historical descriptions. ${ }^{10}$ For example, the dynastic history of the Ptolemies is contained within the description of the monuments of Alexandria (17.1.10-11), and a brief account of the Third Punic War falls within the description of Carthage

\footnotetext{
${ }^{9}$ Pédech (1971) provides a helpful overview of Strabo’s descriptions of cities.

${ }^{10}$ A point made by Dandrow (2015), though he limits his discussion to Strabo's treatment of the Greek world.
} 
(17.3.15). Rome is a special case in Strabo's polis-based historical narrative because it is also an empire. Strabo must therefore account for Rome's growth both as a polis (he begins his description of Latium by calling it "the polis of the Romans:” 5.3.2) and as an empire. He addresses this second aspect of Rome's development most explicitly in the coda to his description of Italy, where he outlines Rome's history of territorial acquisitions up to the reign of Tiberius (6.4). ${ }^{11}$

Strabo emphasizes early in the Geography that even "disappeared" cities have a significant role to play in his description of the oikoumenē. Paraphrasing Demosthenes on Philip of

${ }^{11}$ This section contains some of the latest historical references in the Geography, and may represent an addendum that Strabo composed early in the reign of Tiberius (Roller 2014: 13-16). Although some scholars (e.g., Dueck 1999 and Pothecary 2002) have argued that the entirety of the Geography was composed in the first part of Tiberius' reign, the vast majority of the historical and geographical information it contains refers to the Augustan period or earlier. Moreover, the autobiographical information provided by Strabo himself - most notably, references to his years in Egypt with Aelius Gallus - indicates that he was most active as a traveler and researcher in the last four decades of the first century BC. On the question of the precise date of composition of the Geography, I am inclined to follow Lindsey (1997: 506), who concludes, "With a source which is only sporadically in touch with the contemporary scene, it is more important to have a grip on the age of the main sources of information of the writer, rather than the moment when he penned his text... He himself seems to have considered it a matter of some importance to update his material, and to bring geographical studies into a contemporary focus. This in itself shows that a long time span was involved in composing the work.” 
Macedon’s destruction of Olynthos and other cities ("visitors would never know that they had been settled," ${ }^{12}$ Philippic 3.26), Strabo acknowledges that some cities can be completely obliterated from the physical landscape. However, he maintains that these cities can still contain

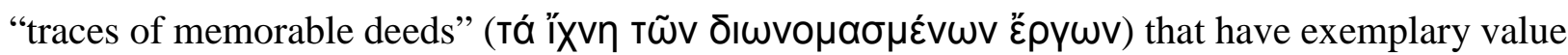
(opheleia) (2.5.17). ${ }^{13}$ Echoing this sentiment, at the outset of his description of the Troad, Strabo

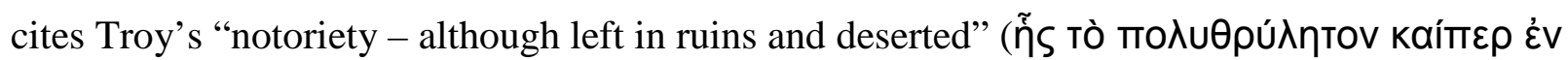

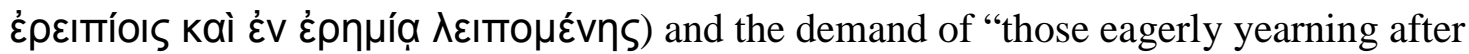

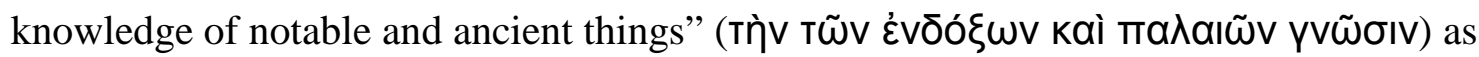
justifications for his lengthy treatment of the city and its environs (13.1.1).

Strabo’s descriptions of Rome and Troy have received considerable attention individually. Scholarly analysis of Strabo's treatment of Rome has mostly focused on the accuracy of his description of the city's topography, or on the Augustan cultural context in which he lived and wrote. ${ }^{14}$ However, there has been little consideration of how Strabo's experience of the city of Rome, both as a historical actor and as a place in the physical landscape, may have affected his conception of urban lifecycles in Italy and in the rest of the oikoumenē. Similarly, analyses of Strabo’s treatment of Troy have focused mostly on his accuracy (or lack thereof). ${ }^{15}$

\footnotetext{
12 English translations are Roller's (2014), unless otherwise indicated.

${ }^{13}$ Greek texts are from Radt’s edition (2002-2011).

${ }^{14}$ For Strabo’s Roman topography, see especially Wiseman 1979. For Strabo’s Augustan cultural context, see García Morcillo 2010 and Vanotti 1992.

${ }^{15}$ Especially Leaf 1923; Franco 2000 is more nuanced, but brief.
} 
Scholars have paid little attention to Strabo's treatment of Rome and Troy together, or to his analysis of the two cities' historical interactions with their respective regions. The relative neglect of this aspect of Strabo's geographical thinking contrasts with the wealth of scholarship on the complex historical and cultural relationship between Rome and Troy expressed in Latin poetry and prose of the Augustan era. It is also a significant omission from studies of Greek perceptions of Troy, and of Roman claims of Trojan ancestry, in the period of Roman imperial expansion that culminated in the reign of Augustus. ${ }^{16}$ Indeed, the Geography's structure - which places seven books totaling some 345 Casaubon pages (approximately 115,000 words) between the descriptions of the two cities - presents a challenge to reading Strabo's Rome and Troy in relation to each other. In addition, as I discuss below, Strabo rejects the evidence of Roman ancestral links to Troy that so many of his literary contemporaries (both Greek and Roman) embraced.

In the rest of this article, I emphasize the originality of Strabo's conception of the lifecycles of cities through his treatment of Rome and Troy as paradigmatic "rising” and "fallen" cities, respectively. Strabo is unique among his Hellenic predecessors and contemporaries in the spatial and chronological scope of his geographical research. Yet, because he relied heavily on earlier works of geography and history to fill out his description of the oikoumene, it can be difficult to separate Strabo's original voice from those of his sources (both named and unnamed). Yet Strabo's descriptions of Troy and Rome - and especially his assessment of these cities' historical

\footnotetext{
${ }^{16}$ Erskine (2001) provides the most complete history of Greek perspectives on Rome’s Trojan origins, though he treats Strabo's account of the Troad mainly as a source for local legends (esp. at 104-106).
} 
interactions with their environs - are highly original, and they are key to understanding his conceptions of urban history and of the current (and future) course of urbanism in the oikoumene. ${ }^{17}$ To Strabo, Rome is the city of the present; its growth and development have determined the course of civilization in the recent past and throughout his own lifetime, and will continue to do so as the oikoumene expands along with the Romans' territorial empire. Troy, on the other hand, is a city of memory: no physical trace of it remains but, thanks to the works of Homer, it lies at the root of all human history and culture. It is present and vivid in Strabo’s text, even if it no longer exists in reality.

Troy, Rome, and the History of Urban Civilization

Strabo’s accounts of Troy and Rome are dissimilar both structurally and in terms of content: while his discussion of Troy is rooted in Homeric geography (naturally), his treatment of Rome focuses on the legends of its foundation and early history, then skips over centuries of Republican history to describe its growth and embellishment in his own day. Yet the descriptions have several commonalities: as I discuss in the next section, Strabo makes clear that both cities

${ }^{17}$ Strabo makes little mention of the future - explicit predictions about Rome and its empire were dangerous ground for writers in the early Principate - but he was clearly mindful of the Geography's prospective uses, since he emphasizes that it is a work intended for the statesman

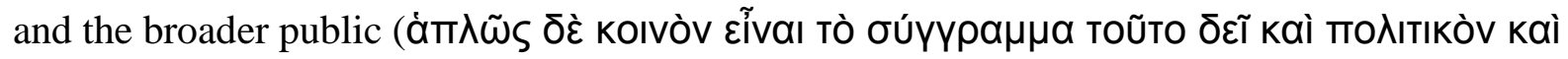
$\delta \eta \mu \omega \varphi \varepsilon \lambda \dot{\varepsilon} \varsigma, 1.1 .22)$. Moreover, he closes his summation of Roman history (6.4.2) with a nod to the future of Rome's imperium in the early years of Tiberius' reign, in the persons of Germanicus and Drusus (both of whom Strabo happened to outlive - another indication of the risks of overt speculation). 
are situated within landscapes of significant urban change over the longue durée - Troy in the Troad, and Rome in Latium.

To a certain degree, Strabo maintains the distance of an outsider with respect to both cities, a reflection of the longstanding role of Romans and Trojans as "others" (though familiar and instructive ones) in Greek culture. ${ }^{18}$ His treatment of Troy is largely academic in nature, as he attempts to refute the misconceptions of earlier generations of scholars regarding the location of Troy and other Homeric toponyms, mostly by following the account of the second-century commentator (and native of the Troad) Demetrios of Skepsis. Likewise, although Strabo must have gained his detailed knowledge of certain aspects of life in Rome - such as the city's firefighting brigade (5.3.7) and the monuments of the Campus Martius (5.3.8) - from personal experience, his account has an impersonal flavor: he speaks in the third-person throughout, never referring to his own time in the city. He takes a scholarly approach to Roman origins, recounting the various legends circulating in his day, and favoring the Romulus and Remus story as "the most faithful account of the founding of Rome” over its alleged foundation by Evander as a

${ }^{18}$ Gruen (2010) offers one view of the relationship between Greek literary culture, Homeric epic, and Roman origins: "The interplay of legend making evades any simple formula. Greek authors converted the sagas of Troy to bring Romans within the matrix of Hellenic traditions. And Romans in turn spun those stories to their own taste, embracing a Trojan lineage that gave them a character distinct from that of Greeks but solidly within the Greek construct. This was no linear development but an intricate overlapping in which Romans defined themselves as a constituent element in a broader cultural network” (247-48). See Erskine 2001: 37-43 for Rome’s Trojan origins as a "Graeco-Roman myth." 
Greek polis (5.3.2-3). In addition, he uses his description of Rome primarily as an opportunity to introduce a Greek readership to the principles of Roman urbanism (5.3.8, discussed below), largely ignoring the city’s public spaces beyond the Campus Martius.

Despite this self-distancing, Strabo had personal experience and familiarity with both cities, though in different ways. From statements he makes elsewhere in the Geography, it is clear that Strabo spent much of his adult life in Rome. ${ }^{19}$ On the other hand, there is no positive indication that he ever visited the Troad; indeed, the numerous glaring errors in his account have led many scholars to conclude that he knew the topography of the region only second-hand, mainly through the work of Demetrios of Skepsis. ${ }^{20}$ Yet Troy loomed large in Strabo's intellectual formation and in his work as a historical geographer. The shape and content of his Geography are informed largely by the epics of Homer - with whom Strabo begins his work, calling him the "originator of the art of geography" ${ }^{21}$ - as well as by the generations of Greek scholars who

${ }^{19}$ He seems to have been in Rome by the early 40s, since he is mostly likely to have seen P. Servilius Isauricus there before his death in $44 \mathrm{BC}$. He visited the Temple of Ceres before it burned down in 31 BC, and also witnessed the execution of the Sicilian bandit Selurus in Rome in the late 30s BC. Josephus (AJ 14.34-36) quotes a passage from Strabo's historical work on his visit to the Temple of Jupiter Capitolinus. See Roller 2014: 2-7 and Dueck 2000: 85-95 for direct and indirect references to Strabo's time in Rome.

${ }^{20}$ Leaf 1923: xxxiv, followed by Franco 2000.

${ }^{21}$ 1.1.2. Strabo goes on to say of Homer, "He alone surpassed everyone, both earlier and later, in the excellence of his poetry and - one might say - his acquaintance with civic life (Tòv ßíov 
attempted to explicate and correct Homeric texts. In addition to Demetrios, in his section on the Troad alone, he cites twenty-four earlier authorities, including geographers (Charon of Lampsakos, Skylax of Karyanda), philosophers (Plato, Aristotle), poets (Alkaios, Sappho), dramatists (Euripides, Aischylos), historians (Timaios, Thucydides), and Homeric scholars (Anaximenes of Lampsakos, Hegesianax).

The history of the library of Aristotle, which Strabo nestles within his description of Demetrios’ hometown of Skepsis (13.1.54), neatly encapsulates the nexus between Homeric legend, Greek intellectual history, and Roman imperialism that implicated Strabo and his Hellenic contemporaries. According to Strabo, Aristotle bequeathed his library to his pupil and successor Theophrastos, and it ended up in Skepsis (along with Theophrastos' own library) in the years after the younger philosopher's death. Due to the neglect and ignorance of its later owners, the library lost much of its value to scholars as books were damaged or lost, then replaced with inferior copies. The library made its way to Athens after its sale to the "bibliophile” Apellikon of Teos, and Sulla “took the library of Apellikon home with him” after his capture of that city (86 BC). In Rome, the grammarian Tyrannion of Amisos (later Strabo’s teacher), who had gained favor in Sulla's circle, recovered and organized the remnants of the library.

The most significant commonality in Strabo’s treatment of Rome and Troy is his effort to place both cities within a broader scheme of the development of civilization. Strabo's explication of the place of Rome and Troy in the history of human settlement represents his most original contribution to the historical geography of each city, and is key to understanding his

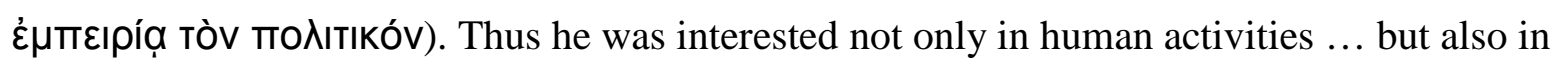
each of the places of the entire inhabited world, both land and sea.” 
conceptualization of the history of urban settlement in the oikoumene. At the center of this conceptualization is the relationship of a city's physical situation to its historical fortunes.

Strabo, following Plato (Lg. 3.677-80; in turn drawing on Homer, Od. 9.112-15 and Il. 20.216-18), places Troy at the mid-point of the emergence of civilization (that is, the formation of an urban lifestyle), as human settlement moved gradually from mountain summits, then to the foothills, then to the plains (where Ilion was situated), and subsequently to the coast and islands (13.1.25). As Strabo explains, “The greater or lesser courage in coming near to the sea would indicate a number of cultural stages and customs, just as the wild customs were the foundation for the simplicity that still remained in some way during the second [i.e. foothill] stage.”22 In Strabo’s understanding, Troy occupied an awkward middle ground in the course of

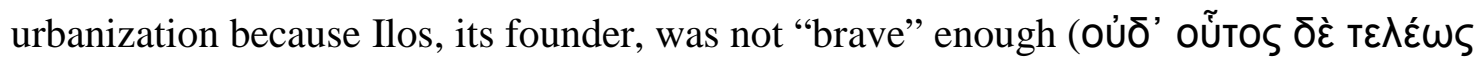

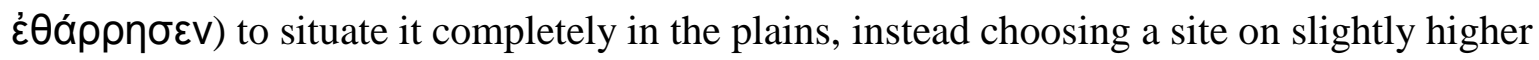
ground. The fuller development of urban civilization was to follow the Homeric era, as the Greeks settled on the coasts and islands of the Aegean, and then throughout the Mediterranean

${ }^{22}$ The text of the next sentence is, unfortunately, difficult to restore: "But there is also a certain difference - that between the rustic, the semi-rustic, and the civilized - from which the gradual [adoption of new names?] ended in urbanity and the best customs, with the change in customs

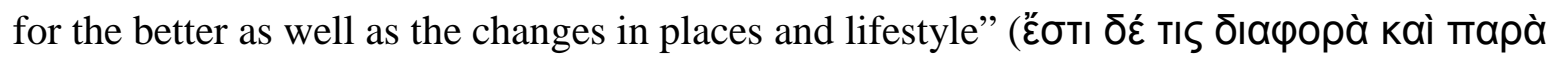

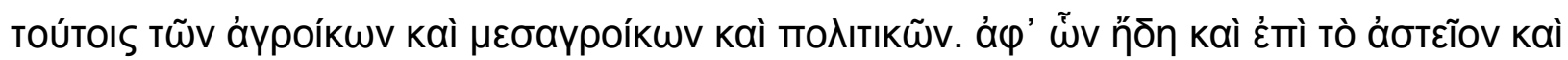

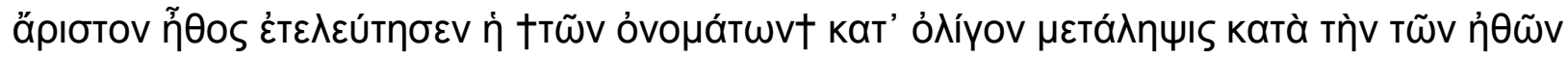

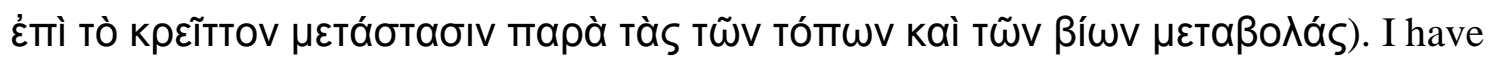
modified Roller’s translation. 
world, paying special attention to the natural advantages of the sites they chose. As Strabo emphasizes in his account of Rome, the success of Greek foundations lay in their "beauty, strength, harbors, and fertile land” (5.3.8). This emphasis, particularly on defensive advantages and harbors, is at the root of Strabo's description of Greek foundations as geographically diverse as Massilia (4.1.4-5), Kyzikos (12.8.11), and Taras (6.3.1-4). ${ }^{23}$

In the same discussion, Strabo emphasizes that Rome does not have the strategic and economic advantages of a properly situated polis - indeed, it was founded in an "unsuitable," exposed location, and at first it lacked a territory because it was surrounded by other settlements (5.3.2, 7). However, the "distinction and hard work" (arete, ponos) of the Romans helped the city to enhance its "natural situation" (euphyia) and expand its territory. The resources of this territory (quarries, forests, and easy transportation by river), facilitated by the "foresight" (pronoia) of the Romans with respect to roads and water supply (aspects of urban life that the Greeks “paid no attention to,” Strabo claims), allowed Rome’s sustenance and further growth (5.3.8). ${ }^{24}$ This growth culminated in the city's embellishment in Strabo's “own time” by Roman leaders like Pompey, Caesar, and Augustus and his family - Strabo singles out the Campus Martius, whose "natural quality" (physis, i.e., its situation as a plain next to a river) has

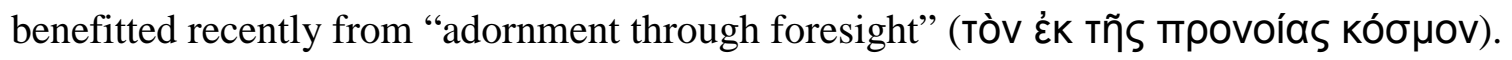

Rome and Troy both had a prime place in Augustan culture, and were linked through the Roman origin stories canonized in the works of Livy, Vergil, Dionysius of Halicarnassus, and

${ }^{23}$ See Trotta 2005 for Strabo’s analysis of Greek colonization.

${ }^{24}$ According to Trotta (2005), Strabo distinguishes natural situation, coupled with human pronoia, as the keys to a successful ktisis, with Rome representing their best synthesis. 
others. Although Strabo pays some attention to these links (e.g., at 13.1.27 and 13.1.41), they do not take up much space in his description of either city; in fact, he omits Aeneas' Trojan origins in his account of the foundation of Lavinium (5.3.2). Indeed, common ancestry is not the primary lense through which Strabo views Rome’s relationship with Greek history and culture, as embodied in Homeric legend. Rather, Strabo subtly - but firmly - denies Rome’s Trojan origins, most extensively in his analysis of the origins of Skepsis and other alleged foundations of Aeneas and his descendants as far afield as Macedonia, Arcadia, Sicily, and Italy (13.1.53). Here, he maintains the authority of Homer's statement, in the prophecy of Poseidon, that Aeneas and his descendants would stay in Troy (Il. 20.306-308), explicitly rejecting (unnamed) Romans' attempts to alter the Homeric text to read "the family of Aeneas will rule everyone." 25

Strabo's rejection of the dominant legend of Rome’s Trojan origins opened up space for original insight into the geo-historical relationship between Troy and Rome. To Strabo - a Hellenic scholar addressing himself to educated, politically active men in cities across the oikoumene ${ }^{26}$ - these two "civilized barbarian" foundations bookend the development of Greek urbanism. Troy lay near the beginning of this development: although its founder had the "courage” (and hence the cultural sophistication) to settle in a coastal plain, he was not "totally courageous," and situated the ancient city on higher ground than the "current” Ilion (13.1.25). The location of Rome, on the other hand, came about "by necessity" rather than "by choice," in a territory already dotted with settlements (5.3.2). However, the superior character and "foresight"

\footnotetext{
${ }^{25}$ See Erskine 2001: 100-101 for the ancient controversy over Poseidon’s prophecy. ${ }^{26}$ Strabo defines his target reader as "someone who has taken the customary curriculum for free men or those pursuing knowledge” (1.1.22).
} 
of the Romans gave them the ability to acquire the territory around them, and to manipulate their environment in order to enhance the natural advantages of their city - a process that reached its apex under Augustus. In the history of Rome, therefore, Strabo sees the culmination of a development manifested in successful Greek settlements now under Roman rule, such as Massilia, whose inhabitants acquired skills in seamanship to make up for the ruggedness of their territory (4.1.5): that is, the synthesis of human pronoia with a site's natural potential to ensure security and growth. ${ }^{27}$

\section{City and Territory: Troy and the Troad, Rome and Latium}

As paradigms of the "fallen" and the "rising" city, respectively, the histories of Troy and

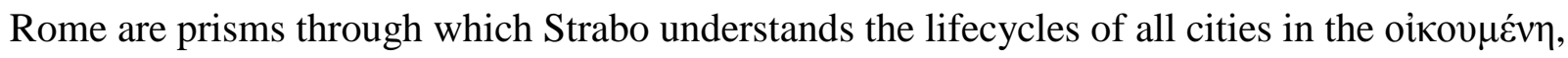
from their birth (i.e. their foundation) to their death (their abandonment, destruction, incorporation into another city, etc.). A key aspect of the lifecycle of any city is its historical interactions with its territory, and Strabo pays close attention to these in his descriptions of Troy and Rome. To Strabo, urban birth and death are not simple, straightforward processes: they also implicate the surrounding territory, and can produce diverse outcomes. The birth and expansion of one city can cause the decline and death of others, in the case of Rome and Latium; and city death can be productive, in the case of Troy and the Troad.

Strabo, following Demetrios of Skepsis, devotes much of his treatment of the Troad to locating the site of Homer's Troy, refuting the claims of the "present" city of Ilion in the process (13.1.25-27 and 35-42). At the heart of this analysis is the question of how a city's identity is constituted: through its physical presence, or its place in collective memory? Also at stake is who

\footnotetext{
${ }^{27}$ Trotta 2005: 127.
} 
inherits and controls a city's memory: in the case of Troy, is it the "present-day" Ilians, or scholars like Demetrios and Strabo, who claim a truer understanding of Homer's works? Furthermore, Strabo must contend with the challenge of embodying a city that he believes has disappeared from the physical landscape - a challenge he alludes to in his introduction to the Troad, where he contrasts the region's literary notoreity with its physical state of ruin and desolation (13.1.1) ${ }^{28}$ He would not normally give a region in this condition such extensive treatment - indeed, he gives short shrift to Messenia (8.4) and Arcadia (8.8) because of their "ruined" state - but the "notable and ancient" (endoxa, palaia) features of the Troad, plus the confusion arising from its post-Homeric settlement history, demand his attention. He must give Troy a presence in his geographical text by defining its former place in the Troad and assessing how it came to be completely obliterated from the physical (but not the mental) landscape.

Strabo's arguments for locating Homer's Troy at the "Village of the Ilians" rather than at the site of "present-day" Ilion (as the "present-day" Ilians and their supporters claim) are taken more or less directly from Demetrios of Skepsis. His key argument for rejecting "present-day” Ilion as the site of Homeric Troy is that "no trace" of the ancient city survives: there is no evidence in Homer that the site was occupied after the Trojan War (13.1.40). In fact, Strabo asserts that Troy was completely destroyed (13.1.41; cf. 13.1.32), citing passages from the Iliad and Odyssey in

28 “The Troad is first on the coast, whose notoriety - although left in ruins and deserted -

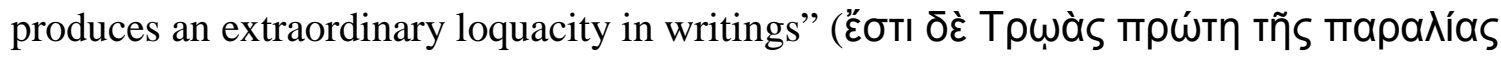

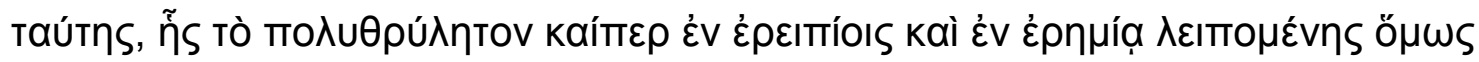

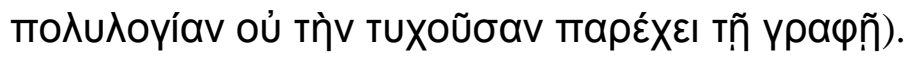


support. ${ }^{29}$ Again citing Homer (Il. 6.92, 9.455; Od. 6.305), Strabo also rejects the Ilians' claim that their xoanon of Athena is the one that was possessed by the ancient Trojans (13.1.41). Implicit in this claim is the centrality of cult to civic identity: the Ilians’ possession of the Homeric xoanon would confirm their affiliation with the Troy of legend. ${ }^{30}$

Strabo concludes his refutation of "present-day" Ilion as the site of the Homeric city by claiming that the destroyed city could not be rebuilt on the same site because of an alleged curse (13.1.42). Therefore, after the first successor settlement, Polion/Polisma, ${ }^{31}$ was razed, the “present settlement” and its sanctuary were founded under the Lydians. Though Schliemann's excavations showed that Greco-Roman Ilion lay on the same site as Homer's Troy at Hissarlik and hence that the Ilians of Demetrios' and Strabo's time were correct ${ }^{32}$ - the issue of whether Strabo was duped by an over-reliance on Demetrios (whose pride as a native Skepsian may have colored his arguments about the antiquity of Ilion) is largely moot. In his account of the Troad,

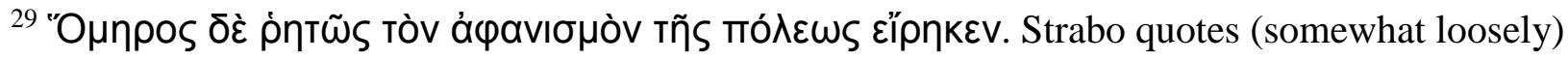
Il. 4.164, 6.448 and 12.15 and $O d .3 .130$.

${ }^{30}$ Such claims of cult continuity could be controversial elsewhere in the oikoumene, as seen in Strabo's rejection of the alternative legend of Rome's foundation by Evander - a legend whose proof the historian Acilius (claims Strabo) found in the Romans' hereditary sacrifice to Herakles “in the Hellenic manner” (5.3.3).

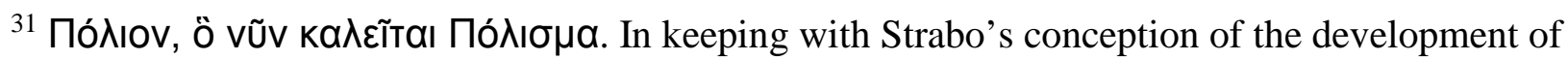
civilization, Ilion was succeeded, literally, by a "town.”

${ }^{32}$ See Rose 2014 for an overview of the excavations and research conducted at Troy since Schliemann's day. 
as elsewhere in the Geography, to the best of his ability, Strabo privileges universal claims especially those made by the Homeric texts - over chronogically and geographically specific ones like the arguments of the "present-day" Ilians. This methodology is also at the root of his rejection of the foundation-stories of Skepsis and other cities (implicitly including Rome) that claim to have been founded by Aeneas and his descendants (13.1.53). Here, the pure Homeric text (“now mighty Aeneas will rule the Trojans...," Il. 20.306-308) takes precedence over the claims of the Skepsians and others, including the Romans who would alter Homer's words to "the family of Aeneas will rule everyone."

In Strabo's telling, the destruction of Homeric Troy was productive in the realms of fact and legend alike. In arguing for the complete destruction of the Homeric city, Strabo must explain what happened to its physical remains: he claims that "although the surrounding cities were pillaged [in the Trojan War], they were not completely destroyed, yet [Troy] was demolished from its foundations and all the stones were taken up and transferred to the others” (13.1.38). Thus, says Strabo, Archeanax of Mitylene allegedly built a wall at nearby Sigeion with its stones. The stones of Troy possessed propagandistic value for the various groups contesting the Troad in the archaic period: the story also circulated that Periander fortified Achilleion (the site of the memorial of Achilles) with stones from Ilion in order to assist the Mitylenaian commander Pittakos against the Athenians. Just as the dispersed stones of Troy were claimed to build or rebuild other cities in the Troad, so the dispersed survivors of the war were the legendary founders of cities in the Troad and across the Mediterranean (13.1.53). Although Strabo rejects 
the legends that involve Aeneas and his sons leaving Troy, ${ }^{33}$ he must acknowledge that these stories were so potent that they led "some" (Romans) to alter the text of the Iliad itself in order to confirm them.

Just as Troy’s fall is, in Strabo’s reckoning, the most significant event in the history and topography of the entire Troad, so his account of Latium is centered on the birth and development of Rome. Strabo cleverly organizes his description of Latium to concurrently narrate the rise of Rome, beginning with the region’s pre-Roman history in the sections describing Sabina and coastal Latium (5.3.1-2); moving to the foundation of Rome and the city’s early interactions with its neighbors (5.3.2-6); then to a description of Rome itself (5.3.7-8); and finally to the other cities of Latium, as defined by the Roman road network (5.3.9-13). ${ }^{34}$ The main theme of these sections is the impact of Rome's development on the geography of the region, from the size and consistency of other Latian cities to the shape of the transportation network supplying the Urbs (roads, aqueducts, canals, etc.).

This theme is introduced at the very beginning, in the account of Sabina, as Strabo describes Kyres, now a komion but once a "notable city” (polis episēmos) that supplied Rome with its early kings Titus Tatius and Numa Pompilius (5.3.1). He notes the fertility of Sabina (especially for

${ }^{33}$ Strabo does not, however, reject the foundation-legends associated with Antenor (cf. 3.4.3 on Iberian Okela, 5.1.4 on the Enetians of northeastern Italy, and 12.3.8 on the Enetians in Paphlagonia).

${ }^{34}$ But this structure entails some repetition, since the course of Strabo's geographical description does not always accord with the pace of his historical narrative, e.g., in the case of Fregellae (5.3.6 and 5.3.10). 
raising olives, vines, acorns, cattle, and mules), as well as the presence of the Via Salaria and the Via Nomentana. As Strabo moves into his description of Latium (5.3.2), in narrating Romulus and Remus' foundation of Rome, he notes that the neighboring towns (polichnia) that first despised the new city (Collatia, Antemnae, Fidenae, Labicum, and others) are "now villages or have been acquired by individuals” (i.e., the estates of Roman aristocrats). ${ }^{35}$

As Rome expanded, it gained the ability to create new cities and to alter the roles of existing ones (5.3.5). King Ancus Marcius founded the port city of Ostia, and generations later, the Romans curtailed the piratical activities of Antium; in Strabo's day, Antium serves as a leisure center, full of the luxury residences of Rome's elite. Although Strabo claims that the Samnites destroyed the ancient Latian cities and sanctuaries associated with Aeneas and the foundation of Rome, the Romans still honor these places "both because Aeneas visited there and for the sacred rites that they say have been handed down from those times." Before he moves into his description of Rome itself (5.3.6), Strabo defines the rest of coastal Latium largely in terms of the Urbs, describing only the cities that the Via Appia touches (Tarracina, Formiae, Minturnae, and Sinoessa), and emphasizing the services the area provides to Rome (luxury retreats, thermal baths, fine wine), as well as the presence of a Roman canal (the Decennovius, constructed in the last years of the Republic).

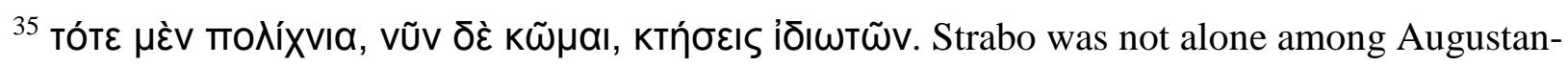
era writers in viewing the expansion of the city of Rome as a potentially destructive force. See Edwards 1996: 52-57 for Propertius' portrayal of Rome's expansion as the cause of the decline of other Latian towns in Elegy 4.1. 
After praising the Romans' ingenuity with infrastructure (roads, sewers, water supply) in his conclusion to the description of Rome itself (5.3.8), Strabo uses the Roman road system to structure his account of the rest of the Latian interior, claiming that "some of [the remaining cities] are distinguished among themselves, and others would largely be defined by the bestknown roads that have been laid through Latium: situated on them, near them, or between them" (5.3.9) ${ }^{36}$ In addition to their relationship to the Via Appia, the Via Latina, and the Via Valeria, Strabo defines the significance of the cities of the interior by the goods and services they render to Rome. Strabo singles out Tibur, Praeneste, and Tusculum as "visible to those from Rome," indicating that he himself had visited them during one of his stays in the Urbs (5.3.11). Tibur (along with nearby Gabii: 5.3.10) is notable for the quarries in its territory, whose products can easily be transported to Rome by river. Praeneste - reputed to be a Hellenic foundation, along with Tibur - is notable for a less salutary service: as a fortified refuge for seditious Romans. Tusculum is noteworthy for its "remarkable constructions in a royal style" (i.e., the luxury villas of aristocratic Romans) (5.3.12). The Fucine Lake supplies a Roman aqueduct, the Aqua Marcia, while Alba, "the farthest in the interior of the cities of Latina," has served the Romans as a prison because of its remote, secure situation (5.3.13).

So far, I have highlighted the special features of Strabo's descriptions of Troy and Rome, and the ways in which he conceives of the historical links between the two cities. In the next section,

${ }^{36}$ Cf. 5.2.10 on the settlements of Umbria, including Forum Flaminium, Nuceria, and Forum Sempronium, "that have increased because of the road [the Via Flaminia] rather than because of

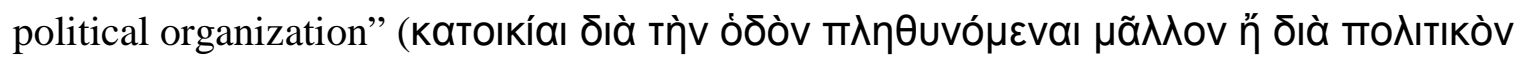

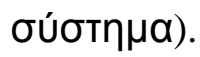


I examine more universal features of Strabo's analysis of Troy and Rome: that is, how the development of the two cities - especially vis-à-vis their territories - mirrors the lifecycles of cities across the oikoumene.

\section{Urban Lifecycles in the Oikoumenē}

In both the Troad and Latium, Strabo highlights patterns of urban birth and destruction that recur throughout his description of the oikoumenē. In Strabo's view, war has had a negative impact on cities throughout the history of urban civilization, causing the complete obliteration of some and the reduction of others to insignificance, starting with the destruction of Troy. At the beginning of his description of Latium, for example, Strabo attributes the disappearance of the Sabine cities to "constant wars” (5.3.1) - the reason he also cites for the devastation of the urban landscape of the southern coast of Sicily (6.2.5), Apulia (6.3.11), the Ambrakian Gulf (7.7), Arcadia (8.8.1), and Akarnania and Aetolia (10.2.23).

However, Strabo must be more nuanced in analyzing the effects of Rome's wars: in most cases, the urban destruction caused by Rome is a (justified) response to revolt, and Roman leaders have made efforts to restore notable cities devastated by warfare. The reactionary nature of Roman warfare is manifested first in Latium, where Rome was founded in "hostile" territory. Strabo says of Rome’s early treatment of its neighbors, “some were destroyed and others humbled because of their disobedience, but some were strengthened because of their goodwill” (5.3.4). He echoes this sentiment in his analysis of Rome's imperial expansion at the end of Book Six, claiming that the Romans "treated the Sabines and Latins as partners, but it did not always happen that they or other neighbors were conciliatory, and, in a way, they were forced to break them up in order to enlarge their own territory” (6.4.2). The Roman conquest of the Eastern Mediterranean, in turn, was prompted by the "revolution” of the Hellenes and 
Macedonians and the wars begun by the Thracians and Illyrians; in the West, the conquest of the Iberians and Kelts followed the same course, and finally, the Romans deposed client kings in Libya, Asia, and further East "if they revolted."

Strabo also highlights Rome's role in the revival of damaged and obsolete cities across the oikoumenē, including Homer's Troy - or rather, its alleged site at “present-day Ilion.” Strabo,

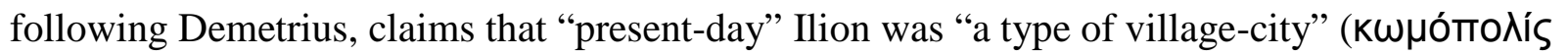
TIS) when the Romans arrived in Asia to fight Antiochus III (192-188 BC) (13.1.27). ${ }^{37}$ Although the city was "later" restored (Strabo does not specify when, or by whom), it was ruined

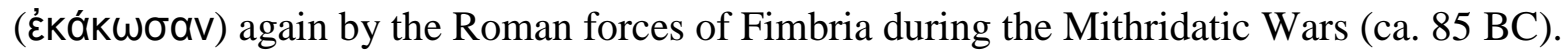
Sulla removed Fimbria and “encouraged the Ilians through much restoration.” During Strabo’s lifetime, Julius Caesar "was much more considerate," and in emulation of Alexander (since both men claimed kinship with the ancient Trojans), "allotted [the Ilians] territory and preserved their freedom and exemption from taxation, and until today they continue to preserve them."38

Strabo cites several other examples of Roman leaders restoring notable ancient cities in the Hellenic world, even if the Romans themselves had been responsible for those cities' destruction or decline. Most notably, he gives a vivid description of Julius Caesar's restoration of Corinth, which the Romans had destroyed in 146 BC, probably based on a visit Strabo had made to the new Roman colony as he crossed the isthmus (8.6.21-23). One of the few other Caesarian or

${ }^{37}$ See Erskine 2001: 226-53 for an overview of Ilion's interactions with the great powers of the Mediterranean world from Alexander to Augustus.

${ }^{38}$ Erskine 2001: 247-51 discusses the evidence for Julius Caesar's treatment of Ilion, and for the city’s Augustan-era building projects (not mentioned by Strabo). 
Augustan colonies that Strabo describes in detail (outside of his homeland of northern Anatolia, of which he had greater first-hand knowledge) is Carthage, another showpiece of Roman restoration (17.3.15). In focusing narrowly on colonies as restorative efforts, Strabo overlooks the disruptive aspects of recent Roman colonization, such as the land confiscations and population displacements that accompanied the settlement of veterans in Italy under Julius Caesar and Augustus. Indeed, Rhegium is the only Caesarian or Augustan colony in Italy that Strabo mentions, highlighting Augustus' role in restoring the city after it had suffered in the Roman civil war and from earthquakes (6.1.6, discussed further below). He also treats the Augustan colonization of Sicily rather selectively: whereas he characterizes the colony at Syracuse in positive terms, as part of Augustus' effort to restore a city damaged by Sextus Pompey (6.2.4), ${ }^{39}$ he makes only a brief mention of the colony at Panhormus (P катогкі́av), and says nothing of the circumstances of its foundation (6.2.5).

Even more significant for the course of urbanization than the Romans' role in restoring cities (or founding new ones) is their role in encouraging the "fusion” or "joining” (synoikismos) of existing cities; in this role, they are the successors of the Hellenistic kings and earlier hegemonic powers. According to Strabo, synoikismos can lead to the disappearance of some cities, the strengthening of others, and occasionally to confusion and controversy regarding a city’s identity. It is perhaps the most significant process of urban change he identifies, taking place in

39 "In our time, as Pompeius had treated the other cities badly, and especially Syracuse, Sebastos

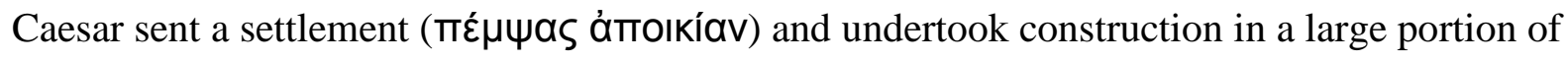
the old district.” The establishment of this colony was probably associated with Augustus’ general "settlement" of the province in 22/21 BC. 
all periods, across the oikoumene, and for a variety of historical reasons, especially in the transition from Hellenic to Roman preeminence.

In the Troad, the most notable example of a polis formed by merging the populations of other cities is Alexandria Troas, founded by Antigonos Monopthalmos as Antigoneia on the site of Sigeia. Lysimachos later renamed it Alexandria (13.1.26), capturing both the cultural cachet of the Troad and the power of the memory of Alexander the Great. Antigonos settled the warring Kebrenians and Skepsians there, though Lysimachos allowed the Skepsians to return to their own city (13.1.33); the territory and population of other nearby towns, including Neandria, were also incorporated into the new city (13.1.47). Roman colonial status (13.1.26) reinforced Alexandria’s emergence as a regional political and economic center, perhaps to the detriment of rivals like Skepsis and “present-day” Ilion. ${ }^{40}$

Although synoikismos had a long history in the Greek world, to Strabo, it has new significance under Roman hegemony, as a means of spreading Roman juridical status and cultural practices. Strabo understands Rome's expansion into Latium - and the extension of the rights associated with Roman citizenship to neighboring peoples - mainly as a process of “fusion” following conquest in war. Existing cities retain their physical presence and autonomy, but they take on Roman identity, especially through the bestowal of Roman citizenship and/or the settlement of Roman citizens, and eventually become part of Roman territory. Strabo gives

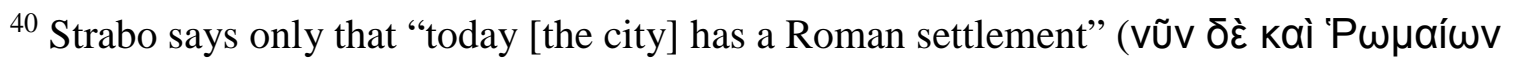

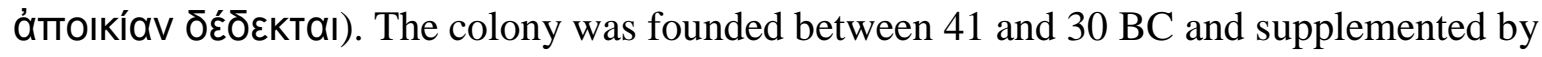
additional veteran settlers between 27 and 12 BC, possibly receiving Ius Italicum at the same time (Rose 2014: 234).
} 
the most detail about the incorporation of Alba (5.3.4). "In the beginning," he claims, the Albans lived "in harmony" with the Romans because of their shared Latin language and identity. Although ruled separately by distinct monarchies, citizens of the two cities intermarried (i.e., possessed conubium), had common sanctuaries at Alba, and had "other political rights in common." "Later" the two cities went to war, Alba was sacked (except for the sanctuary), "and

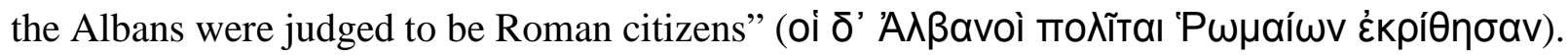

Strabo also understands recent Roman colonization in the Western Mediterranean as a process of synoikismos of separate populations: i.e., Romans and natives. He describes the Augustan colonies of Pax Augusta, Augusta Emerita, and Caesaraugusta in Iberia as "jointly

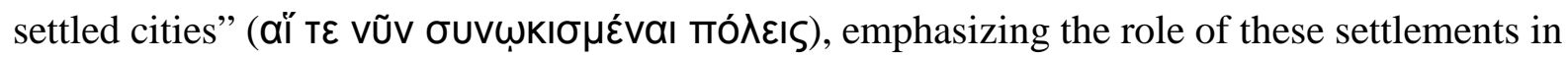
the Romanization of the native population (3.2.15). ${ }^{41}$ Under the Romans, synoikismos also plays a role, alongside the foundation of new cities, in the pacification of troublesome populations, from the tribes of Lusitania (3.3.5) to the pirates that Pompey settled in Lycia (14.3.3). Additionally, the Romans use synoikismos to restore population and political order to devastated, depopulated regions; most notably, Strabo characterizes Augustus’ establishment of Nikopolis on the Ambrakian Gulf after the battle of Actium as an act of settlement restoration through

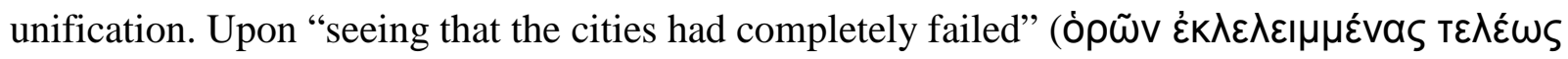

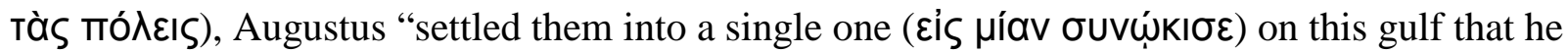
called Nikopolis” (7.7.6). Strabo’s broad but inconsistent use of the language of “joint settlement" (synoikismos and its variants), inter alia to describe the resettlement of existing

\footnotetext{
41 "Most of [the Turdetanians] have become Latins, and have taken Romans as settlers, so they are not far from being completely Roman.”
} 
urban populations in a new location (in the case of Nikopolis) and the addition of a new population of Roman colonists to an existing civic body (in the case, for example, of Rhegium $^{42}$ ), suggests that in spite of his recognition of the intermixing of Roman and nonRoman populations as a significant aspect of the spread of Roman law and culture (beginning with Alba, in Rome’s Latian heartland), he does not understand all of the juridical nuances of Roman alterations to the constitutions and civic bodies of existing poleis.

In Strabo’s treatment of the Romans' restoration of damaged cities and territories, we can perceive an understanding that, as with urban planning and infrastructure, the Romans' approach to the movement and resettlement of populations departs from that of the Greeks (including the Hellenistic kings). Positioned on the cusp of the Principate, Strabo could see, but could not fully grasp the implications, of the spread of the Roman civitas not only to the barbarian West, but also to the world of the Greek politeia. ${ }^{43}$ To conclude, I summarize some of the ways in which Strabo begins to conceptualize the current state (and, perhaps, the future) of urbanism in the oikoumene, especially through the development of Rome itself.

\section{Conclusion}

${ }^{42}$ 6.1.6: “Caesar, having thrown Pompeius out of Sikelia and seeing that the city was lacking in

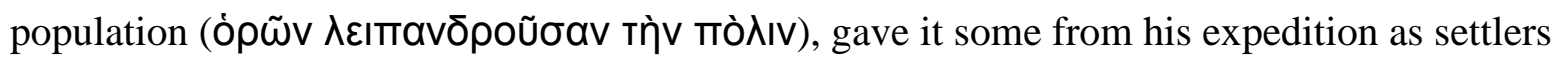

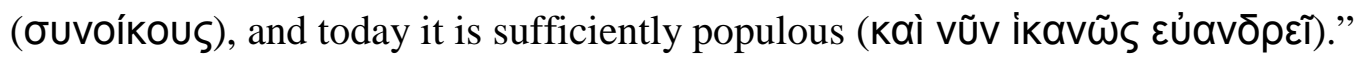

${ }^{43}$ Ando (2012) claims that “Strabo's diction also gives voice to an abortive engagement with an alternative framework within which to understand culture and identity change, namely that of citizenship and ultimately of public law, of civitas in all its meanings” (121). 
Strabo reflects most extensively on the history of urbanism in his accounts of Troy and Rome. Troy, though not a Hellenic city itself, represented an early step in the emergence of Greek civilization, as men began to settle on coastal plains - and to take advantage of the opportunities for movement and exchange that these locations afforded - rather than remaining protected, but isolated, on hilltops. The growth of Rome, also not a Hellenic city, represented a further stage in civilization's development: the city was founded by necessity, despite its geographic disadvantages; however, its inhabitants' unprecedented attention to the infrastructure of roads and waterways allowed it to grow and to gain hegemony in its region - and later, over the entire oikoumene. Implicit, perhaps, in Strabo's contrast of Roman urbanism (founded on strategic necessities, and emphasizing urban infrastructure and amenities) with the Greek urbanism (based on topographic and hydrological suitability) that had its origins in the Homeric era is the notion that the former will replace the latter as Roman imperium continues to extend into the "wilder" areas North, West, and East of the Mediterranean littoral: while Greeks took care to choose sites suitable for cities, Romans concentrate on making their sites suitable to be cities.

As Ando (2012) has emphasized, Strabo's text reflects an inchoate Greek understanding of Roman urbanism - and particularly its juridical aspects - at the dawn of the Principate. Furthermore, Strabo had no direct experience of the western Roman provinces - he probably traveled no further West than the Tyrrhenian coast of Italy - so his contact with Roman urbanism came mainly from his time in Rome, as a witness to its growth and embellishment under Augustus, and from his youth in Pontus, where, following the defeat of Mithridates, Pompey had recently overseen the reorganization of the settlement hierarchy, with new Hellenic poleis supplanting old royal power centers (cf. 12.3). Although Strabo could not use the vocabulary of 
the Greek polis to fully and adequately describe the uniqueness of the Roman civitas, such experiences, as well as his long and deep engagement with geographic traditions rooted in the Homeric epics, would have positioned him well to appreciate the historical roots of Roman urbanism, and to begin to identify the distinctive features that drove its development in his own lifetime. In this respect, Strabo’s Geography is quite characteristic of the cultural atmosphere of the Augustan era: as they lived through the unprecedented process of the Roman state consolidating its rule over the oikoumene just as it came under the control of a single man, Strabo and his contemporaries found innovative ways of using the shared cultural heritage of the GrecoRoman Mediterranean (including legends about the fall of Troy and the escape of its combatants) to explain their new world, and to gain insight into its potential development. ${ }^{44}$

\section{$\underline{\text { References }}$}

Ando, C. 2012. “The Roman City in the Roman Period.” In S. Benoist, ed., Impact of Empire, Volume 16. Rome, a City and Its Empire in Perspective: The Impact of the Roman World through Fergus Millar's Research, 109-24. Leiden.

Clarke, K. 1999. Between Geography and History: Hellenistic Constructions of the Roman World. Oxford.

Dandrow, E. 2015. “Memory and the Greek city in Strabo’s Geography.” In A.M. Kemezis, ed.,

${ }^{44}$ Edwards' (1996, 56) comment on Book Four of Propertius’ Elegies could equally be applied to Strabo’s urban landscapes: "Rome itself has undergone a reverse transformation from rustic landscape to glittering city. But we may wonder if the destruction of other cities which has formed an essential part of Rome's growth may not also be read as portending a possible future for Rome.” 
Urban Dreams and Realities in Antiquity, 438-54. Leiden.

Dueck, D. 1999. “The Date and Method of Composition of Strabo’s ‘Geography.”’ Hermes 127.4: 467-78.

-----------. 2000. Strabo of Amasia: A Greek Man of Letters in Augustan Rome. London and New York.

Edwards, C. 1996. Writing Rome: textual approaches to the city. Cambridge.

Erskine, A. 2001. Troy between Greece and Rome: Local Tradition and Imperial Power. Oxford.

Franco, C. 2000. “La Troade di Strabone.” In A.M. Biraschi and G. Salmeri, eds., Strabone e l'Asia Minore, 261-82. Naples.

García Morcillo, M. 2010. “The Glory of Italy and Rome’s Universal Destiny in Strabo’s Geographika.” In P. Liddel and A. Fear, eds., Historiae Mundi: Studies in Universal History, 87-101. London.

Gruen, E. 2010. Rethinking the Other in Antiquity. Princeton.

Hardie, P. 2013. “Trojan Palimpsests: The Archaeology of Roman History in Aeneid 2.” In J. Farrell and D.P. Nelis, eds., Augustan Poetry and the Roman Republic, 107-23. Oxford.

Kraus, C. 1994. “'No Second Troy:’ Topoi and Refoundation in Livy, Book V.” TAPA 124: 26789.

Leaf, W. 1923. Strabo on the Troad. Cambridge.

Lindsay, H. 1997. “Syme’s Anatolica and the date of Strabo’s Geography.” Klio 79.2: 484-507. McKenzie, J. 2007. The Architecture of Alexandria and Egypt, c. 300 B.C. to A.D. 70. New Haven.

Nelis, D. 2015. “Vergilian Cities: Visions of Troy, Carthage and Rome.” In T. Fuhrer, F. Mundt, 
and J. Stenger, eds., Cityscaping: Constructing and Modelling Images of the City, 19-45. Berlin and Boston.

Pédech, P. 1971. “La Géographie urbaine chez Strabon.” AncSoc 2: 234-53.

Pothecary, S. 2002. “Strabo, the Tiberian Author: Past, Present and Silence in Strabo’s Geography.” Mnemosyne 55.4: 387-438.

Radt, S. 2002-2011. Strabons Geographika. 10 vols. Göttingen.

Roller, D. 2014. The Geography of Strabo. Cambridge.

Rose, C. B. 2014. The Archaeology of Greek and Roman Troy. Cambridge.

Trotta, F. 2005. "The foundation of Greek colonies and their main features in Strabo: a portrayal lacking homogeneity?” In D. Dueck, H. Lindsay, and S. Pothecary, eds., Strabo’s Cultural Geography: The Making of a Kolossourgia, 118-28. Cambridge.

Urso, G. 2001. “Roma ‘città greca’: nota a Strabone V 3,5,232.” Aevum 75.1: 25-35.

Vanotti, G. 1992. “Roma e il suo impero in Strabone.” In M. Sordi, ed., Autocoscienza e rappresentazione dei popoli nell'antichità, 173-94. Milan.

Wiseman, T. P. 1979. “Strabo on the Campus Martius: 5.3.8, C235.” LCM 4: 129-33. 